\title{
Gold Investment from Islamic Perspective: The Case of Malaysia
}

\author{
Syed Ehsanullah Agha ${ }^{1}$, Abdul Rahman Saafi ${ }^{1}$ \& Obaidullah Abdul Qayoom ${ }^{2}$ \\ ${ }^{1}$ Institute of Islamic Banking and Finance, International Islamic University Malaysia, Malaysia \\ ${ }^{2}$ INCEIF (The Global University of Islamic Finance), Malaysia \\ Correspondence: Syed Ehsanullah Agha, Institute of Islamic Banking and Finance, International Islamic \\ University, Jalan Gombak, 53100 Kuala Lumpur, Selangor, Malaysia. E-mail: Ehsanaagha@gmail.com
}

Received: November 20, 2014

doi:10.5539/ijef.v7n5p179

\begin{abstract}
Gold investment in Malaysia offers a secure asset class for investors through two different ways, physical gold and "paper gold" (gold account). Investment in physical gold enables investors to diversify their portfolio. Gold account, on the other hand, allows investors to make deposits when gold prices are low and withdraw the funds at profit when the gold price rises. It is noted that there is insufficient studies examining the issue of gold investment in Malaysia. Accordingly, this paper is expected to be among the first studies seeking to provide a comprehensive discussion on the gold investment in the context of Malaysia, examining its operations, contemporary applications; and the associated shariah compliance issues. In this respect,it attempts to clarify the status of gold investment from an Islamic perspective. The study adopts the qualitative research method. The discussion is limited to Gold Bars, Exchange Traded Products (ETPs), Gold Savings Account, Central Bank Gold Financing and Mining Companies. This study serves as a good guideline for Muslim investors.
\end{abstract}

Keywords: gold investment account, Shariah compliance, Islam

\section{Introduction}

For centuries, metals have been given great importance in human life. Fights, battles and even wars were recorded in the book of history over time. Among all of those metals, gold is the only one which keeps its intrinsic value. Because of the affection to this metal it was given the status of the currency or medium of exchange over the time. As a reliable store of value, gold fulfills the unique functions of money. It is portable, divisible, indestructible, and scarce and cannot creatively be produced.

Gold is deemed to be a stable mean in order to hedge against inflation, store intrinsic value, and preserve wealth besides generating high level of return. It fulfills the function of money as accepted forms of payment internationally. Besides, gold's low-to-negative correlation with bonds and stocks makes it an excellent and great portfolio diversifier. In reality, many financial consultants recommend keeping $4 \%$ to $12 \%$ of individual's total assets in the form of gold.

\subsection{The Gold Market}

Studies that look at the financial characteristics of gold include Sherman (1982), Kaufmann and Winters (1989), Faugere and Van Erlach (2006) and Lucet et al. (2006). Based on their studies, central banks hold a large proportion of gold reserves for several reasons: economic security where gold maintains its purchasing power, portfolio diversification, physical security where gold is a highly liquid asset, provides confidence during economic uncertainty, secure value and as a hedging tool against economic crisis.

\subsection{Gold as a Safe Haven Asset}

The current economic uncertainty and the gold price strength motivate people to explore the gold viability as a safe haven asset from losses in financial markets. Baur and Lucey (2010) prove the potential of gold as a safe haven asset. Based on their study, gold tends to hold its value when the stock markets experience extreme negative returns in the United States (US) United Kingdom (UK) and Germany. Besides, Capie et al. (2005) analyze the role of gold as a hedging tool against the dollar, finding evidence of the exchange-rate hedging potential of gold. McCown and Zimmerman (2006) examine a few of gold characteristics as a financial asset and find an evidence of the gold as an inflationary hedge. Their findings suggest gold has criteria of zero beta assets and bearing zero market risk. 


\subsection{Gold as an Investment Instrument}

Gold played a great role as a precious metal with significant portfolio diversifier (Ciner, 2001). Other studies highlighted the benefits of gold in an efficient and balanced portfolio (Sherman, 1982;Aggarwal \& Soenen, 1988; Johnson \& Soenen, 1997; Ciner, 2001; Egan \& Peters, 2001; Davidson et al., 2003; Draper et al., 2006). In Malaysian perspective, Ibrahim (2012) reported that there are significant contributions of gold investment during economic uncertainty especially when the stock market slumps. Baharom and Ibrahim (2011) assessed whether gold investment provides diversification, hedge, or safe haven benefit for the case of Malaysia using daily data from August 2001 to March 2010.

\section{Research Design}

This paper adopts qualitative research method, relating to the growing issues of gold investment in Malaysia. Data sources include interviews, texts and documents (i.e. archival research), specifically from the Central Bank of Malaysia (BNM), National Fatwa Council Malaysia, gold miners, gold manufacturer companies, bank product disclosure sheet, newspaper articles, magazines, goldsmiths and author's analysis.

\section{Discussion and Analysis}

There are myriad methods of gold investment such as trading of gold bars, investing in paper gold, shares trading of gold miners, gold unit trust funds or unit in exchange-traded funds (ETFs) that hold physical gold. In Malaysian market, investors have a few ways of gold investment, gold bars and coins, gold savings accounts and gold unit trust funds. The criteria of each type of investment vary, depending on the types and the seller. Investors are advised to choose the gold-based vehicle that best suited their expected return, needs, risk profile and portfolio. By analyzing the advantages and disadvantages of each method, this paper will benefit those who are interested in this type of investment.

\subsection{Gold Bullion, Bars or Coins}

The most traditional way in gold investment is buying a physical gold, whether gold bar bullion or coins. In countries like Canada, Argentina, Austria, Liechtenstein, Switzerland and Malaysia banks can easily buy and sell gold bars from common public on the same time there are private dealers that do the same transactions in the open market. Gold bar has different sizes like in Europe, gold bars are mostly 400 troy ounces $(12 \mathrm{~kg}$ ) also $1 \mathrm{~kg}$ or $32 \mathrm{ozt}$ (Lawrence, 2003).

Bars generally carry lower price premiums than gold bullion coins. However, larger bars carry an increased risk of forgery due to their less stringent parameters for appearance. While bullion coins can be easily weighed and measured against known values, most bars cannot, and gold buyers often have bars re-assayed. Larger bars also have a greater volume in which to create a partial forgery using a tungsten-filled cavity, which may not be revealed by an assay (Lucey, 2006).

There are certain ways to avoid such scams, most commonly used among them is to buy bars and keep them within the London bullion market (LBMA) and store the gold in LBMA certified vault. These certified vaults can be bought and sold easily. If it is removed from the vaults and stored outside of these certified vaults, for example stored at home or in a private vault, the bar will have to be re-assayed before it can be returned to the LBMA chain. This process is described under the LBMA's "Good Delivery Rules" (Lawrence, 2003).

Kijang Emas Gold Bullion Coins are Malaysia's own gold bullion coins that provide an alternative form of investment to the public. It has a purity of $99.99 \%$ fineness and sold by BNM through their trusted agent, i.e. Maybank. It is available in three different sizes, which are $1 / 4 \mathrm{oz}, 1 / 2 \mathrm{oz}$ and $1 \mathrm{oz}$. The design on the obverse of each coin depicts a barking deer (kijang) in its natural habitat in the jungle of Malaysia. In order to facilitate selling and buying transaction, the Kijang Emas is priced at the daily gold market price based on the international market price.

Banks in Malaysia are also offering a wide range of physical gold products (bars and coins) that are available for investors, goldsmiths and coin collectors. A large variety of gold coins are made available for investments. These gold coins are available in different sizes, ranging from $1 / 20 \mathrm{oz}$ to 100 grams. The gold coins can be bought or sold from or to the banks at their daily buy-sell market prices.

\subsection{Exchange Traded Products (ETPS)}

Gold exchange-traded products may include ETFs, ETNs, and CEFs which are traded like shares on the major stock exchanges. The first gold ETF, Gold Bullion Securities (ticker symbol "GOLD"), was launched in March 2003 on the Australian Stock Exchange, and originally represented exactly 0.1 troy ounces $(3.1 \mathrm{~g})$ of gold. As of November 2010, SPDR Gold Shares is the second-largest exchange-traded fund (ETF) in the world by market 
capitalization.

Gold ETPs represent an easy way to gain exposure to the gold price, without the inconvenience of storing physical bars. However exchange-traded gold instruments, even those which hold physical gold for the benefit of the investor, carry risks beyond those inherent in the precious metal itself. For example the most popular gold ETP (GLD) has been widely criticized, and even compared with mortgage-backed securities, due to features of its complex structure (Commission, 2013).

Typically a small commission is charged for trading in gold ETPs and a small annual storage fee is charged. The annual expenses of the fund such as storage, insurance, and management fees are charged by selling a small amount of gold represented by each certificate, so the amount of gold in each certificate will gradually decline over time.

\subsection{Gold Savings Account or "Paper Gold"}

Instead of investing in physical gold, banks in Malaysia are offering a gold savings account or paper gold to the public. This is a statement-based gold investment account which provides opportunity of investment in gold without the inconvenience of storing and transferring the physical gold. It is secured and hassle free investment method, offering high liquidity to account holders as they can sell their holdings to the bank during trading hours. Currently, there are seven banks that offer this type of gold investment. They are Maybank, Public Bank, CIMB Bank, Kuwait Finance House (KFH), Citibank, UOB Bank and Standard Chartered Bank. This type of account is normally open for individuals with aged 18 years and above, while some banks allow for the minors as well (Gold investment in Malaysia, 2013).

One of the interesting characteristics of this investment is that it allows the investor to open a joint account with a maximum number of 4 persons in one account. The price of gold quoted on a daily basis and will be pegged to the global market price. This is better than goldsmith shops that normally charge high workmanship charges. The recommended time for investors to buy would be when the price of gold is low. The returns on this account are subject to the world gold price fluctuations and this investment product is not insured by Malaysia Deposit Insurance Corporation (PIDM). This account provides an instant liquidity, where investors can cash in on their investments at any time during banking hours.

There are a few benefits of gold investment by opening a gold investment account. Basically, this investment will provide an opportunity for greater capital gain from the gold price appreciation. Besides the potential better returns, gold provides an efficient platform to diversify investor's portfolio. Gold savings account also serves the same functions of providing a good hedge against inflation by holding physical gold. Investments are well protected in which the account is fully backed by physical gold. The main reason for the investors to invest in gold investment by depositing in gold savings account is the affordability and convenience aspects that allow people to buy or sell gold and withdraw it easily with their account at the bank's branches in Malaysia. Gold purchase or sale will be based on the bank's prevailing gold buying and selling price quoted in Ringgit Malaysia (RM) per gram and normally the mode of payments accepted are through cash and debiting or crediting of current or savings account maintained with the bank.

When investors purchase gold through the gold savings account, this is recorded into a passbook. In this case, the bank keeps the gold in their safe custody for the investors, and interest is not paid for this service. There are two main risks involved in this type of investment, which is pricing risk and market risk. In this case, gold buying or selling price quoted shall be determined by the bank at its sole and absolute discretion taking into account all factors it deems relevant including the prevailing international and local market price conditions for gold, the exchange rate between USD and RM and the gold purity.

Maybank Gold Investment Account (MGIA) is the only gold savings account that allows investor to start their gold investment by buying only 1 gram of gold, while the others normally start with 5 grams or 10 grams. The MGIA is an account which allows customers to invest in 999.9 fine gold commodities at a daily price in RM without the hassle of keeping physical gold. MGIA are fully backed by physical gold deposited in PAMP S.A. and the returns are dependent on the gold price fluctuations. Transactions performed would be recorded in a MGIA passbook.

In the case of UOB Bank, this bank is offering two types of gold savings account, namely Premier Gold Account (PGA) and Gold Savings Account (GSA). Both accounts had similar characteristics, except for the minimum investment, whereby PGA needs a minimum investment of 1 kilogram of gold, while GSA only requires a minimum of 20 grams of gold. UOB gold savings account could be considered as the best gold savings account available in the market since the price spread is very low, RM3 per gram for GSA account and only RM2 per gram 
for PGA account. Investors may convert their gold savings account to the physical gold subject to the bank's approval with some fees.

KFH Gold Account- $i$ is the only Shariah-approved gold savings accounts in Malaysia that allows customers to make a gold deposit in a convenient, secured and cheap way. This savings account applies the Shariah concept of Bai' as-Sarf and Qardh al-Hassan. Bai' as-Sarf refer to the exchange of one monetary form for another in the same or different form on a spot basis, where in this case it refers to the exchange of the money with gold. Under this contract, an investor will buy the gold from $\mathrm{KFH}$ in gram at the selling price determined by KFH. Meanwhile, Qardh refers to benevolent 'loan' or interest-free 'loan' whereby KFH as the borrower is only required to return the commodity or principal borrowed. Under this contract, the gold bought by the investor will be deposited into the gold account with $\mathrm{KFH}$ as the debtor (Muqtaridh) and the investor as the creditor (Muqridh).

With KFH Gold Account- $i$, investors can conveniently invest and trade in gold. This account allows investors to track and plan their investments wisely as trades are recorded in their account statement. It is different compared to the Maybank Gold Investment Account (MGIA), in which this KFH Gold Account- $i$ is a non-passbook account. Like other gold savings account, besides enjoying the peace of mind purchasing gold without having to keep it in the physical form, investors in this account may withdraw the physical gold on the spot or have the bank retain the gold under Qardh al-Hassan concept. For the purpose of withdrawal, investors must deposit the account in a denomination of $1,5,10,20,50$ or 100 grams. This is due to the availability of physical gold held by the bank. There are also no charges imposed on the gold safekeeping and withdrawal. Unlike other types of gold savings accounts, KFH Gold Account- $i$ also allows organisational investors to invest through the non-individual account. It is open for associations, societies, companies or other business entities that $\mathrm{KFH}$ Malaysia finds suitable or acceptable.

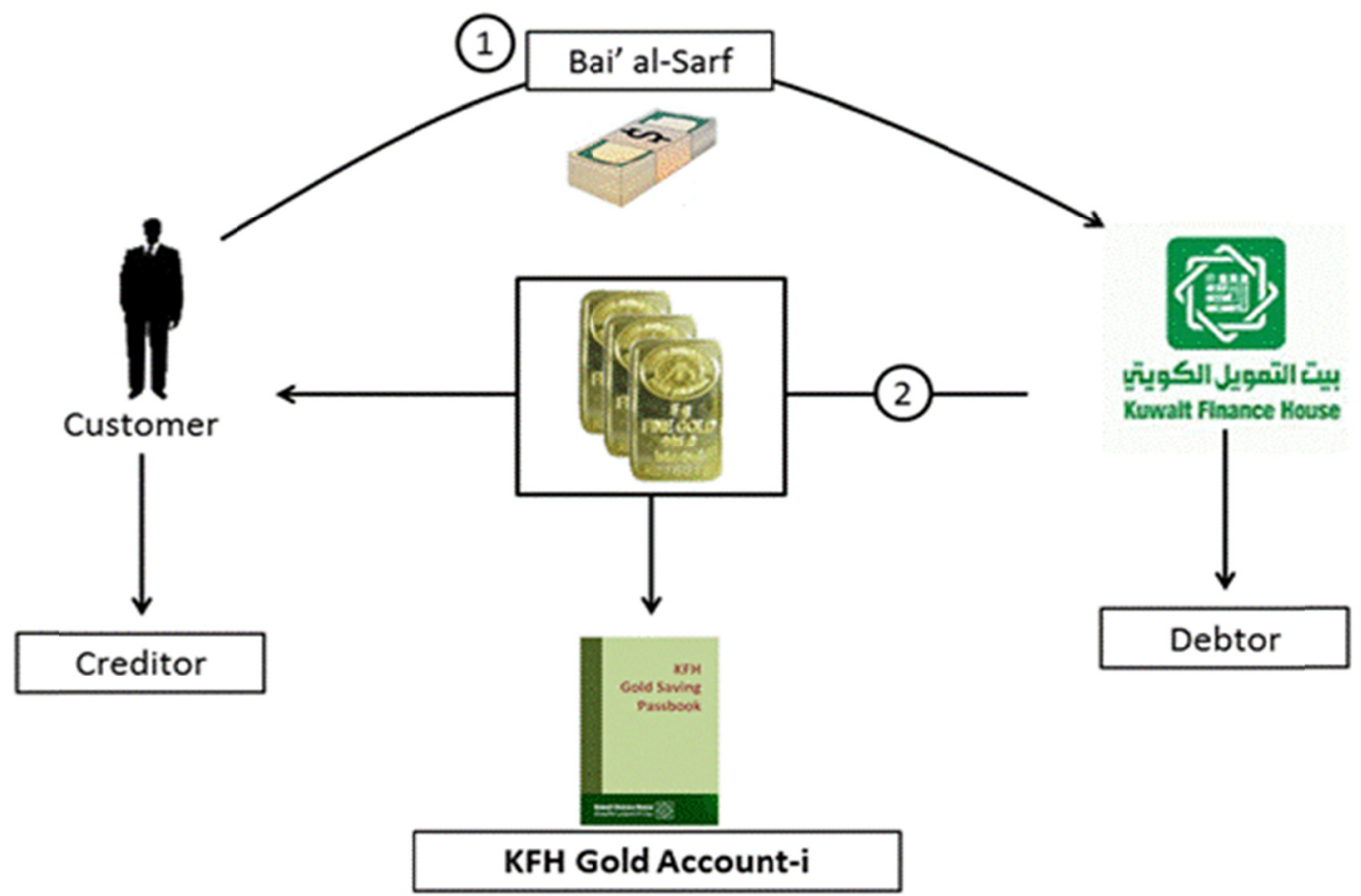

Figure 1. Transaction for KFH gold account-i

Source: www.kfh.com.my.

\subsection{Mining Companies}

They are like normal corporate institutions registered in the stock market. The share price of these companies increases when the gold price rises. Nevertheless, there are some other factors that can influence the share price like unsystematic risk (Steel, 2011). Generally speaking; due to the inherent leverage in the mining sector the 
gold price is unstable compared to other commodities.

\subsection{Central Bank Gold Financing}

In some countries central bank gives out gold to commercial banks so that they can earn some profits from the rising trends of gold price in the market. Central bank give out certain amount of gold to commercial banks which they sell in the gold market and buy securities. These securities are most of time government. T-bills. After a certain pre determine period banks sell these government securities in the secondary market and buy back the gold and return it back to the central bank. As the gold prices are on an upward trend hence there is no loss of central bank, on the other hand it saves the cost of keeping gold in its vault (Phillips, 2012) As central bank has given this gold to many commercial banks hence they will sell and buy the gold at the same time, which can affect gold prices in the market causing fluctuations. Diagrammatically this process can be.

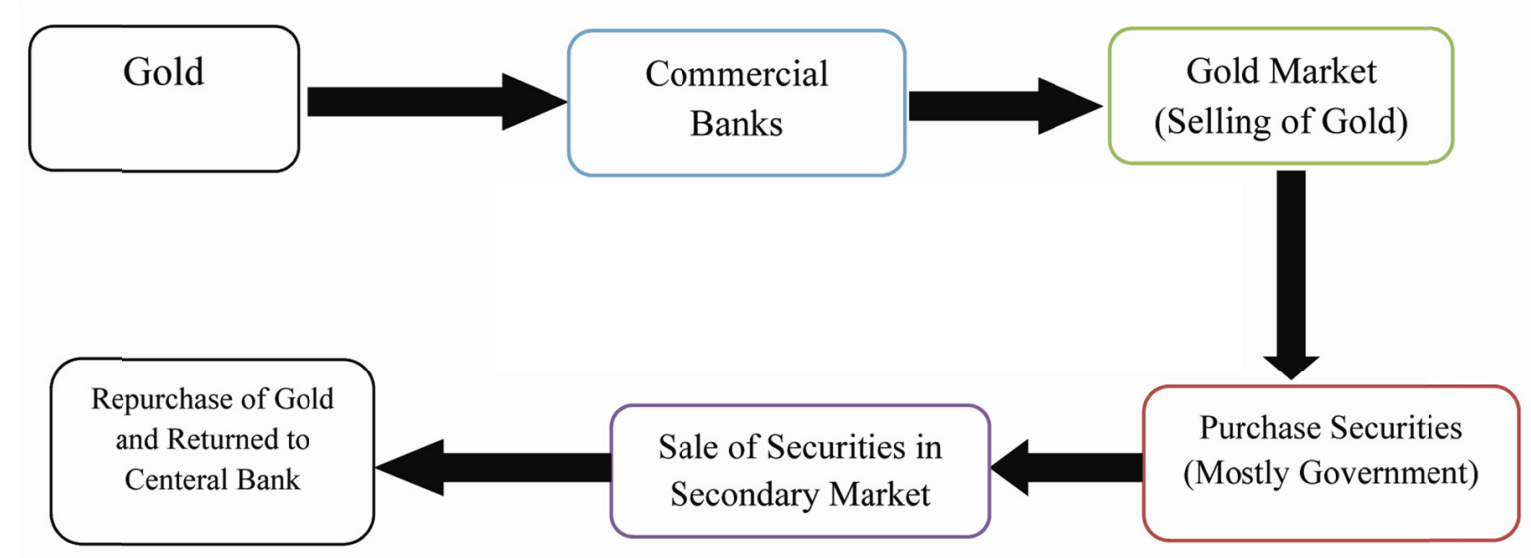

\section{Challenges and Shariah Issues}

Today, some of the countries in the world such as China and India are encouraging their citizens to buy gold due to its characteristics of safe haven and inflationary hedge. This phenomenon urges Malaysians to do the same by keeping some percentage of their asset and wealth in gold. Government has to take the action by disseminating the ideas of keeping and storing individual's asset and wealth in gold. This requires the Malaysian government to continue the production of Kijang Emas as a national gold coin and to make it available and accessible to people through most of the domestic banks. Government should also monitor the selling and buying activities of other types of gold bars and coins.

Fundamentally, when a customer intends to open a gold investment account, he is agreeing to buy gold, keep it and probably sell it when the price goes up. Depending on the prevailing situations, any type of such gold investment account can fall into different $H u k m$ (ruling) namely:

i. Haram and Void: If the gold is not yet owned by the bank and will only be bought from a third party in another separate transaction. The opening of such investment account has become Haram and void, because the bank has sold something which is not in its rightful possession. Since there is no element of 'Taqabud fil Majlis' i.e. offer and acceptance during the same event, any such delay would bring to Riba' an-Nasiah (according to majority of scholars). As well as if the bank or seller owned the gold, but didn't deliver the gold or what represent the gold at spot like in case of gold derivatives, central bank gold financing, and Exchange Traded Products.

ii. Haram and Void: If the gold is not delivered, upon request to the customer immediately at opening of the gold investment account. This happens for example, when the customer pays a certain amount of money to buy gold and activates his account, but the bank did not issue anything to prove that the sale has been concluded. In this situation, the bank has not given a written proof to signify that the customer now has the 'tasarruf' (the rights to sell the gold, which has been purchased, at any point of time).

iii. Halal and Valid: When both conditions stated below are met:

a) The bank rightfully owns the gold at the point of sale.

b) The bank issues a proof of purchase, in the form of physical gold or certificate, to the customer and thus immediately gives the customer his right of 'tasarruf'. 
It is necessary for the bank to clarify to their customers in regards to the status of their gold savings accounts, whether they are shariah-approved or not. As far gold investment accounts are concerned the study has found that only KFH-I is shariah-approved,. The other two banks, Maybank and Citibank are found to be conventional-based and did not fulfil the approval requirement, and this may be due to the fact that investors in Maybank and Citibank cannot withdraw their gold savings account deposits in the physical form. The other four banks have a potential to be shariah-approved provided that they meet the following conditions, namely:

i. Not to be involved with Riba' activities: The gold must be in the real form (physical) which is in the custody of the bank, and kept on behalf of the customer. The gold cannot be 'utilized' for any of the bank's ribawi activities, and a guarantee or confirmation from the bank or the bank's shariah Committee must be obtained either expressed or written. A customer should be able to ascertain the from the 'aqad (contract) entered with the bank, whether it is a wadiah, qard, or etc..

ii. Enough gold during transaction: The amount of gold in the bank's possession must be ascertained to be enough during a particular sales transaction period. For example, if the bank has only 100 kilograms of gold at a particular point of time, but sells (with the opening of the gold investments account) to two different customers 100 kilograms of gold each. In this case, only the first completed transaction is deemed as valid, while the second transaction is deemed as void.

iii. Halal method of payment: Payment made by customers must be either in cash, immediate account debiting, local bank's Islamic debit or credit card, or local cheque.

Any payment for such gold purchase using international cheque or Islamic credit card which takes more than three days for 'settlement' is prohibited according to the International Council of Fiqh Academy (ICFA). Three days are taken as the maximum accepted number of days for settlement, based on normal standard or 'urf, to ensure the requirement under 'taqabul fil hal' is achieved.

The gold investments account holder must be paying zakat: Whenever the hawl is fulfilled and the obligatory nisab of 85 grams of gold is reached or exceeded, the account holder is obligated (wajib) to pay zakat (Gold Investment in Malaysia, 2013).

\section{Conclusion}

Instead of the traditional way of buying the physical gold, Malaysia offers investors a unique platform of gold investment. This method of investment has a great potential to overcome the issues of security and storage. We explored and discussed the challenges and prospects of gold investment by describing different ways of gold investment in Malaysia, weighing the pros and cons of each option. The shariah compliance issues have also been discussed. Out of seven banks, only one bank offer shariah-approved gold savings accounts. However, this was based on a famous juristic view that considers the exchange of Gold with paper currency as "Bayu lsarf” (بيع "Bayu contract .On the other hand, According to Mufti Taqi Iusmani (1988) this transaction is not "Bayu lsarf" because he holds the opinion that paper currency is like metal coins (فلوس). According to this view in the case of exchanging gold with paper currency only one counter value must be exchanged on the spot. We propose for BNM to impose requirements of shariah screening on gold savings accounts offered by banks. Recent trend shows that Malaysians are increasingly turning to gold investment as one of the shariah-compliant mechanisms to protect wealth. This study thus shall benefit investors, especially Malaysians.

\section{References}

Aggarwal, R., \& Soenen, L. A. (1988). The nature and efficiency of the gold market. Journal of Portfolio Management, 14(3), 18-21. http://ssrn.com/abstract=1908650

Al-Usmani, T. (1988). Ahkam Alawraq Al naqdiya. Retrived from http://www.kantakji.com/media/4625/c347.doc

Baharom, A. H., \& Mansor, H. I. (2011). Financial Investment in Malaysia: The Role of Gold. In Perspective, A Quarterly Newsletter by Taylor's Business School. Retrieved from http://9icief.sesric.org/presentations

Bailey, W. B. (1987). An empirical investigation of the market for Comex Gold futures options. Journal of Finance. http://dx.doi.org/10.1093/rfs/14.3.837

Baker, S. A., \& Van-Tassel, R. C. (1985). Forecasting the price of gold: A fundamentalist approach. Atlantic Econ. J., 13, 43-52. http://dx.doi.org/10.1002/(SICI)1096-9934(199605)16:3\%3C313::AID-FUT4\%3E3.0.CO;2-

Baur, D. G., Lucey, B. M. (2010). Is gold a hedge or a safe haven? An analysis of stocks, bonds and gold. The Financial Review. http://dx.doi.org/10.1111/j.1540-6288.2010.00244.x 
Beelders, O. (2003). An investigation of the unconditional distribution of South African Stock index returns. Applied Financial Economics, 13(9), 623-633. http://dx.doi.org/10.1093/rfs/12.5.975

Cai, J., Cheung, Y. L., \& Wong, M. C. S. (2001). What moves the gold market? Journal of Futures Markets, 21(3), 257-278. http://dx.doi.org/10.1002/1096-9934(200103)21:3<257::AID-FUT4>3.0.CO;2-W

Capie, F., Mills, T. C., \& Wood, G. (2005). Gold as a hedge against the dollar. Journal of International Financial Markets, Institutions and Money, 15, 343-352. http://dx.doi.org/10.1016/S0378-4266(02)00323-0

Ciner, C. (2001). On the long run relationship between gold and silver: A note. Global Finance J., 12, $299-303$. http://dx.doi.org/10.1016/S1044-0283(01)00034-5

Davidson, S., Faff, R., \& Hillier, D. (2003). Gold factor exposures in international asset pricing. Int. Financial Markets Inst. Money, 1-19. http://dx.doi.org/10.1016/j.eneco.2012.01.006

Dionne, G., \& Garand, M. (2003). Risk management determinants affecting firms' values in the gold mining industry: New empirical results. Economics Letters, 79(1), 43-52. http://dx.doi.org/10.1016/S0165-1765(02)00286-0

Egan, P., \& Peters, C. (2001). The performance of defensive investments. J. Altern. Investments, 4, 49-56. http://dx.doi.org/10.1257/jel.41.2.478

Farchy, J. (2012). Central banks increase gold lending. Retrieved from http://www.ft.com/cms/s/0/c2b92910-40fe-11e1-b500144feab49a.html\#axzz1ug0esJKj

Faugere, C., \& Van Erlach, J. (2006). The price of gold: A global required yield theory. Journal of Investing, 14, 99-111. http://dx.doi.org/10.3905/joi.2005.479394

$\begin{array}{lllll}\text { Fpmarkets. } & \text { (n.d.). } & \text { Commodity } & \text { CFDs. } & \text { Retrieved }\end{array}$ http://www.fpmarkets.com.au/cfds/cfd-types/commodity-cfds.php

Gaithry, S. A. (2011). A study on Islamic pawn broking awareness and factors influencing the scheme in Sungai Petani, Kedah. 2nd International Conference on Business and Economic Research. Retrieved from http://www.internationalconference.com.my/proceeding/icber2011

Johnson, R., \& Soenen, L. (1997). Gold as an investment asset-perspectives from different countries. J. Investing, 6, 94-99. http://dx.doi.org/10.3905/joi.1997.408427

Kaufmann, T., \& Winters, R. (1989). The price of gold: A simple model. Resour. Policy, 19, 309-318. http://dx.doi.org/10.1016/0301-4207(89)90004-4

Koutsoyiannis, A. (1983). A short-run pricing model of a speculative asset tested with data from the gold bullion market. Appl. Econ., 15, 563-582. http://dx.doi.org/10.1080/00036848300000037

Lawrence, C. (2003). Why is Gold Different from other Assets? An Empirical Investigation. World Gold Council, London. Retrieved from http://www.gold.org/research/why-gold-different-other-assets-empirical-investigation

Lucey, B. M., Tully, E., \& Poti, V. (2006). International portfolio formation, skewness and the role of gold. Frontiers in Finance and Economics 3, 1-17. Retrieved from http://citeseerx.ist.psu.edu/viewdoc/summary?doi=10.1.1.149.150

Lucey, B., \& Tully, E. (2006). Seasonality, risk and return in daily comex gold and silver 1980-2002. Appl. Financial Econ., 16, 519-533. http://dx.doi.org/10.1080/09603100500386586

\section{Copyrights}

Copyright for this article is retained by the author(s), with first publication rights granted to the journal.

This is an open-access article distributed under the terms and conditions of the Creative Commons Attribution license (http://creativecommons.org/licenses/by/3.0/). 